Check for updates

Cite this: RSC Adv., 2018, 8, 7173

\title{
Suppressing self-discharge of $\mathrm{Li}-\mathrm{B} / \mathrm{CoS}_{2}$ thermal batteries by using a carbon-coated $\mathrm{CoS}_{2}$ cathode $\uparrow$
}

\begin{abstract}
Youlong Xie, (D) Zhijian Liu, (D) * Huilong Ning, (D) Haifeng Huang (D) and Libao Chen (iD
Thermal batteries with molten salt electrolytes are used for many military applications, primarily as power sources for guided missiles. The $\mathrm{Li}-\mathrm{B} / \mathrm{CoS}_{2}$ couple is designed for high-power, high-voltage thermal batteries. However, their capacity and safe properties are influenced by acute self-discharge that results from the dissolved lithium anode in molten salt electrolytes. To solve those problems, in this paper, carbon coated $\mathrm{CoS}_{2}$ was prepared by pyrolysis reaction of sucrose at $400{ }^{\circ} \mathrm{C}$. The carbon coating as a physical barrier can protect $\mathrm{CoS}_{2}$ particles from damage by dissolved lithium and reduce the selfdischarge reaction. Therefore, both the discharge efficiency and safety of $\mathrm{Li}-\mathrm{B} / \mathrm{CoS}_{2}$ thermal batteries are increased remarkably. Discharge results show that the specific capacity of the first discharge plateau of carbon-coated $\mathrm{CoS}_{2}$ is $243 \mathrm{~mA} \mathrm{~h} \mathrm{~g}^{-1}$ which is $50 \mathrm{~mA} \mathrm{~h} \mathrm{~g}{ }^{-1}$ higher than that of pristine $\operatorname{CoS}_{2}$ at a current density of $100 \mathrm{~mA} \mathrm{~cm}{ }^{-2}$. The specific capacity of the first discharge plateau at $500 \mathrm{~mA} \mathrm{~cm}^{-2}$ for carbon-coated $\mathrm{CoS}_{2}$ and pristine $\mathrm{CoS}_{2}$ are $283 \mathrm{~mA} \mathrm{~h} \mathrm{~g}^{-1}$ and $258 \mathrm{~mA} \mathrm{~h} \mathrm{~g} \mathrm{~g}^{-1}$ respectively. The characterizations by XRD and DSC indicate that the carbonization process has no noticeable influence on the intrinsic crystal structure and thermal stability of pristine $\mathrm{CoS}_{2}$.
\end{abstract}

Received 5th December 2017 Accepted 5th February 2018

DOI: 10.1039/c7ra13071f

rsc.li/rsc-advances
Different from conventional LiCl-KCl eutectic electrolyte, LiF$\mathrm{LiCl}-\mathrm{LiBr}$ molten salt system has an ionic conductivity up to $6.52 \mathrm{~S} \mathrm{~cm}^{-1}$.5,6 Thus the $\mathrm{Li}-\mathrm{B} / \mathrm{LiF}-\mathrm{LiCl}-\mathrm{LiBr} / \mathrm{CoS}_{2}$ couple is now the most suitable assembly for the high-power output thermal batteries. However, the free lithium in Li-B alloy is very easy to dissolve into the electrolytes. Then the dissolved lithium diffuses to the cathode and reacts with cathode materials once thermal batteries are activated, which results in serious selfdischarge at discharge. Above phenomenon can be related to the rule that alkali-metal had a considerable solubility in molten alkali halide. ${ }^{7}$ The solubility of lithium at $\mathrm{LiF}-\mathrm{LiCl}-\mathrm{LiBr}$ eutectic is between $1 \mathrm{~mol} \%$ and $2 \mathrm{~mol} \%$, which was measured by Watanabe N. ${ }^{8}$ The Li activity of the anode has a dramatic influence on increasing the dissolving process and Li-B alloy has much higher Li activity than $\mathrm{Li}-\mathrm{Si}$ alloy and $\mathrm{Li}-\mathrm{Al}$ alloy. Therefore the capacity of $\mathrm{Li}-\mathrm{B} / \mathrm{CoS}_{2}$ cells is more greatly influenced by the severe self-discharge especially in the case of long operating life thermal batteries. Self-discharge rate of $\mathrm{Li}-\mathrm{B} / \mathrm{LiF}-$ LiCl- $\mathrm{LiBr} / \mathrm{CoS}_{2}$ cells measured by Gao was up to $20 \mathrm{~mA} \mathrm{~cm}{ }^{-2},{ }^{9}$ which is almost times more than $\mathrm{Li}-\mathrm{Si} / \mathrm{CoS}_{2}$ cells. In addition, a drastic exothermic reaction accompanied with self-discharge reactions, may destroy the battery and cause serious safety issues. So far, performances of $\mathrm{Li}-\mathrm{B} / \mathrm{CoS}_{2}$ batteries are still limited by self-discharge.

Various strategies have been employed to address the selfdischarge caused by dissolved lithium in $\mathrm{Li}-\mathrm{B} / \mathrm{LiF}-\mathrm{LiCl}-\mathrm{LiBr} /$ $\mathrm{CoS}_{2}$ cells. Zeng reported that applying additive of nanometal powder to $\mathrm{LiF}-\mathrm{LiCl}-\mathrm{LiBr}$ electrolytes could effectively suppress the dissolution of lithium anode. ${ }^{\mathbf{1 0}}$ Different from Zeng,
State Key Laboratory of Powder Metallurgy, Central South University, Changsha 410083, China. E-mail: csulzj1208@163.com; Tel: +86 13974870130

$\dagger$ Electronic supplementary information (ESI) available. See DOI: 10.1039/c7ra13071f 


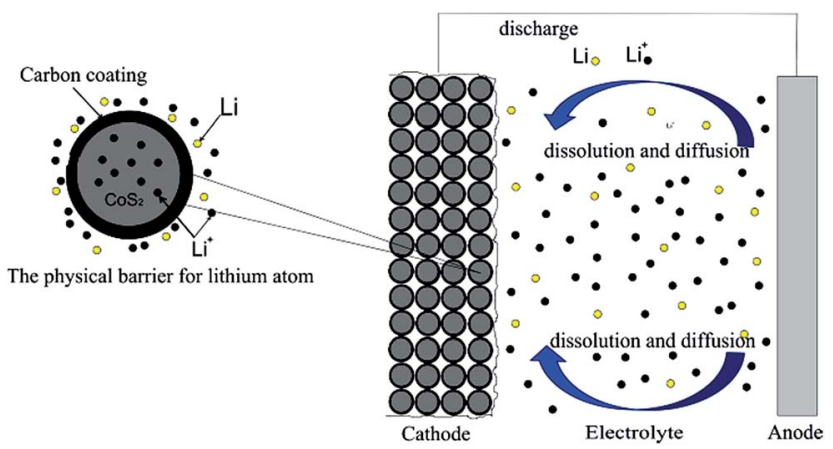

Fig. 1 The influence of modifying $\mathrm{CoS}_{2}$ cathode materials by the carbon coating at thermal batteries.

preventing direct contact between dissolved lithium and active cathode materials through surface modification may be another promising strategy in solving this problem. Similar strategies have been applied to suppress the harmful interaction between electrode materials and electrolytes for lithium ion batteries. ${ }^{11-13}$ The alumina coating for lithium cobalt fluorophosphate was reported to prevent metal ion dissolution and improve the cycle performance. ${ }^{14} \mathrm{~A}$ widely recognized interpret is that the alumina coating can protect cathode materials from hazardous reaction products such as $\mathrm{HF}$ obtained during the charge-discharge process. ${ }^{15,16}$ Petnikota has modified $\mathrm{FeO}$, $\mathrm{MnO}$ and $\mathrm{Co}_{2} \mathrm{Mo}_{3} \mathrm{O}_{8}$ by coating of graphene oxide for anode application in lithium ion batteries. All of those composites exhibit better electrochemical properties than corresponding pristine batteries. ${ }^{17-19}$ Another example is that amorphous carbon coating is used to prevent PC-based electrolytes insert into graphite accompanied by graphite exfoliation. ${ }^{20,21}$ For researches of thermal batteries that anode is $\mathrm{Li}-\mathrm{Si}$ alloy, carbon coating to $\mathrm{CoS}_{2}$ cathode was reported by Xie to promote electrochemical properties by enhancing the electronic conductivity. ${ }^{22}$

In this paper, considering the higher self-discharge rate at $\mathrm{Li}-\mathrm{B} / \mathrm{CoS}_{2}$ system, the carbon coating of $\mathrm{CoS}_{2}$ is mainly aimed to block dissolved lithium atom react with $\mathrm{CoS}_{2}$ cathode. Based on above hypothesis, we reported a facile method through pyrolysis reaction of sucrose, to modify $\mathrm{CoS}_{2}$ with amorphous carbon coating (this composite of carbon and $\mathrm{CoS}_{2}$ is referred as $\mathrm{CoS}_{2} / \mathrm{C}$ hereafter). It has been proved that $\operatorname{CoS}_{2} / \mathrm{C}$ was suitable for thermal batteries and successful in reducing self-discharge rate at $\mathrm{Li}-\mathrm{B} / \mathrm{CoS}_{2}$ system. Discharge tests indicated that $\mathrm{CoS}_{2} / \mathrm{C}$ released higher capacity than pristine $\mathrm{CoS}_{2}$. Fig. 1 illustrates how the carbon coating influences self-discharge as a physical barrier.

\section{Experimental}

\section{Carbon-coated $\operatorname{CoS}_{2}$ preparation}

$\mathrm{CoS}_{2}$ was powder from State Key Laboratory of Powder Metallurgy which was synthesized by solid-state reaction of cobalt and sulphur powder. ${ }^{8}$ To prepare carbon-coated $\mathrm{CoS}_{2}, 1 \mathrm{~g}$ sucrose $\left(\mathrm{C}_{12} \mathrm{H}_{22} \mathrm{O}_{11}\right)$ was dispersed in $2 \mathrm{~mL}$ pure water. Then, $9 \mathrm{~g}$
$\mathrm{CoS}_{2}$ and sucrose solution were ground together for $1 \mathrm{~h}$ to make it been mixed evenly. After drying, the mixture was carbonized in the argon atmosphere for $4 \mathrm{~h}$ after heating to $400{ }^{\circ} \mathrm{C}$ at a rate of $5{ }^{\circ} \mathrm{C} \min ^{-1} \cdot{ }^{23-25}$

\section{Single cell preparation}

Anodes were Li-B alloys strip which were provided by State Key Laboratory of Powder Metallurgy, and synthesized by smelting metal lithium and boron. ${ }^{26}$ Mass fraction of lithium for $\mathrm{Li}-\mathrm{B}$ alloy is $61 \mathrm{wt} \%$. It was punched to disk with a diameter of $17.5 \mathrm{~mm}$. Electrolyte were composed by $50 \mathrm{wt} \% \mathrm{LiF}-\mathrm{LiCl}-\mathrm{LiBr}$ eutectic salts (9.2 wt\% LiF, $22 \mathrm{wt} \% \mathrm{LiCl}, 68.4 \mathrm{wt} \% \mathrm{LiBr})$ and $50 \mathrm{wt} \%$ Nano-MgO binder. Cathodes include $80 \mathrm{wt} \% \mathrm{CoS}_{2}$ or $\mathrm{CoS}_{2} / \mathrm{C}$ and $20 \mathrm{wt} \%$ electrolytes.

The cathode and separator were shaped to stratiform slice together by spreading the corresponding powders in a die, and then suppressing them under a static compaction pressure of $250 \mathrm{MPa}$. Two types of single cells were prepared to study the electrochemical properties of anode and cathode respectively. Single cells that the anode was superfluous were composed of $0.20 \mathrm{~g}$ anode, $0.36 \mathrm{~g}$ separator and $0.18 \mathrm{~g}$ cathode. While single cells with superfluous cathode were composed of $0.09 \mathrm{~g}$ anode, $0.36 \mathrm{~g}$ separator and $0.40 \mathrm{~g}$ cathode. Single cells with $\mathrm{CoS}_{2} / \mathrm{C}$ and pristine $\mathrm{CoS}_{2}$ cathode were abbreviated as $\mathrm{CoS}_{2} / \mathrm{C}$ cell and $\mathrm{CoS}_{2}$ cell respectively hereafter.

\section{Materials characterization}

Microscopic morphology studies were carried by the scanning electron microscope (LEO 1530 Gemini, Zeiss, Germany) at $15 \mathrm{kV}$. Crystalline structures of samples were characterized by X-ray diffractometer (D/max2550PC, Rigaku, Japan) at a rate of $8^{\circ} \min ^{-1}$ from $10^{\circ}(2 \theta)$ to $90^{\circ}(2 \theta)$ with $\mathrm{Cu} \mathrm{K} \alpha$ radiation. Differential scanning calorimetry (DSC) was conducted by a thermal analyzer system (Hengjiu, Beijing) with a heating rate of $10{ }^{\circ} \mathrm{C} \mathrm{min}^{-1}$ and a $50 \mathrm{ml} \mathrm{min}^{-1} \mathrm{Ar}$ flow rate. The carbon coating was observed by transmission electron microscopy (Tecnai G2, FEI, USA). Raman spectroscopies were completed by (T64000, Horiba, Japan) and $514 \mathrm{~nm}$ light was used for excitation with an intensity of $20 \mathrm{~mW}$. Particle size distribution was measured by laser particle size analysis (Mastersizer3000, Malvern, England).

\section{Electrochemical measurements}

Anode, separation-cathode disk were fabricated to single cell. The test was conducted at $520{ }^{\circ} \mathrm{C}$ with a fluctuation of $5{ }^{\circ} \mathrm{C}$. Single cells were discharged at constant current and pulse current respectively. In pulse discharge, the current densities were ranged from $100 \mathrm{~mA} \mathrm{~cm}{ }^{-2}$ to $600 \mathrm{~mA} \mathrm{~cm}^{-2}$ for $2 \mathrm{~s}$ every $20 \mathrm{~s}$ to study total polarization and power properties. Discharge data were obtained by electronic load (ITECH, IT8511, USA). Total polarization was calculated by following formula. ${ }^{27}$

$$
R_{\mathrm{total}}=\Delta U / \Delta I
$$


here $R_{\text {total }}$ denotes the total polarization of a single cell. $\Delta U$ denotes the voltage drop caused by pulse current. $\Delta I$ denotes the difference between pulse current and steady current.

\section{Results and discussion}

X-ray diffraction patterns of both $\mathrm{CoS}_{2} / \mathrm{C}$ and pristine $\mathrm{CoS}_{2}$ are shown in Fig. 2a. All peaks of pristine $\mathrm{CoS}_{2}$ and $\mathrm{CoS}_{2} / \mathrm{C}$ can be indexed to a pure-phase, and no apparent differences appear between $\mathrm{CoS}_{2}$ and $\mathrm{CoS}_{2} / \mathrm{C}$ patterns, except the whole diffraction intensity. It indicates that the coating process has no affection on the crystal structure of pristine $\operatorname{CoS}_{2}$. Besides, no peaks involved to carbon are observed in diffraction patterns of $\mathrm{CoS}_{2} /$ C. Fig. $2 b$ is the results of XRD analysis of Li-B alloy anode. It shows that Li-B alloy was mainly made up of free lithium metal and LiB compound. According to past studies, no free lithium metal was appeared at $\mathrm{Li}-\mathrm{Si}$ or $\mathrm{Li}-\mathrm{Al}$ alloy anode. It is the free lithium metal that makes the Li-B alloy has much more activity than that of $\mathrm{Li}-\mathrm{Si}$ or $\mathrm{Li}-\mathrm{Al}$ alloy.

Fig. 3a and b display SEM images of pristine $\operatorname{CoS}_{2}$ and $\operatorname{CoS}_{2} /$ $\mathrm{C}$ respectively. Both pristine $\mathrm{CoS}_{2}$ and $\mathrm{CoS}_{2} / \mathrm{C}$ show aggregation which is sticked by tiny spherical particles. There are gaps and
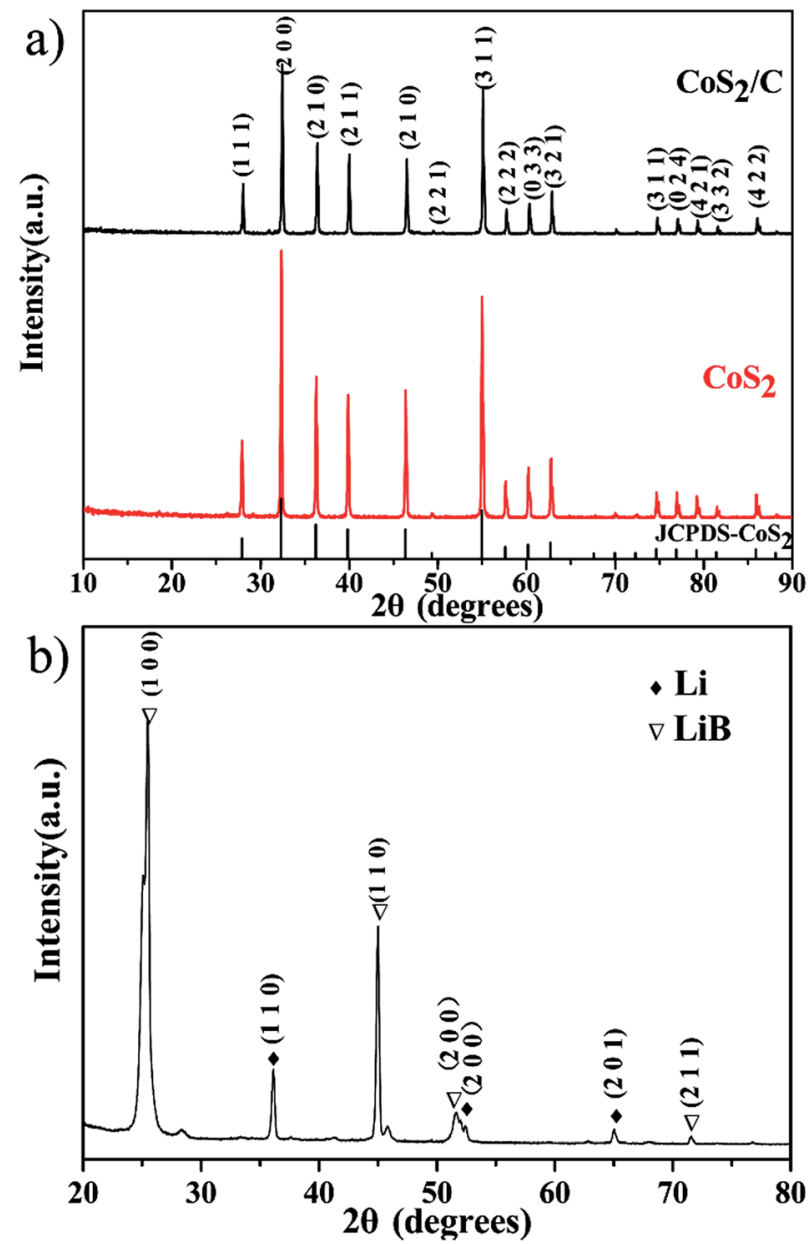

Fig. 2 XRD patterns of $\mathrm{CoS}_{2} / \mathrm{C}$ and pristine $\mathrm{CoS}_{2}$ (a). XRD patterns of Li-B alloy anode (b).

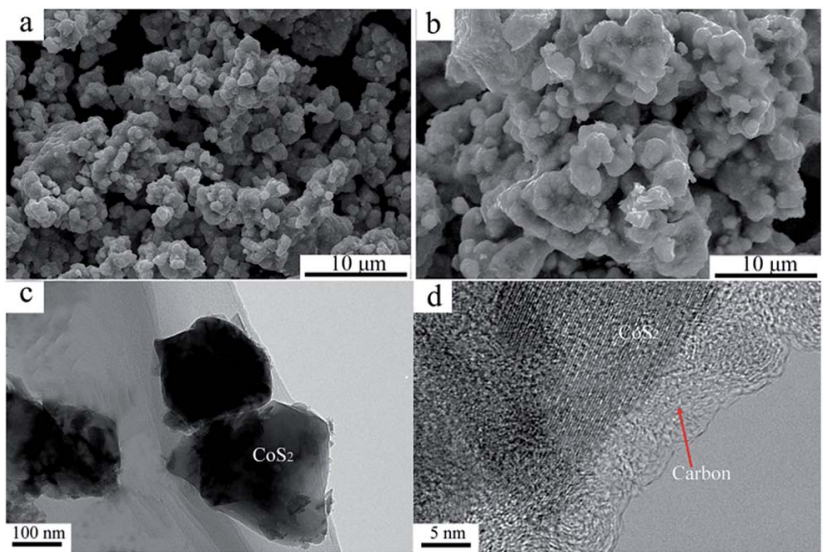

Fig. 3 SEM images of pristine $\operatorname{CoS}_{2}$ (a) and carbon-coated $\mathrm{CoS}_{2}$ (b). TEM images of carbon-coated $\mathrm{CoS}_{2}(\mathrm{c}, \mathrm{d})$.

holes between tiny spherical particles, which can provide the passageway for molten electrolytes at the process of discharge. Compared Fig. 3a and b, $\operatorname{CoS}_{2} / \mathrm{C}$ has bigger granularity than pristine $\mathrm{CoS}_{2}$. This phenomenon can be explained by bonding of sucrose. Since the melting point of sucrose is $186{ }^{\circ} \mathrm{C},{ }^{28}$ sucrose will be heated to the liquid state before the carbonized stage and $\mathrm{CoS}_{2}$ particles may be bonded by viscous molten sucrose. The changes of granularity observed by SEM are also identical to the consequence of particle size analysis. Median particle diameter (D50) of pristine $\mathrm{CoS}_{2}$ is increased from $19.7 \mu \mathrm{m}$ to $26.8 \mu \mathrm{m}$ after coating. Fig. $3 \mathrm{c}$ and d show the TEM micrographs of $\operatorname{CoS}_{2} / \mathrm{C}$ particles. There is a clear boundary between the core of $\mathrm{CoS}_{2}$ and the bright translucent shell materials of the carbon. The thickness is estimated to be $6 \mathrm{~nm}$. The combination between $\operatorname{CoS}_{2}$ and carbon is proved to be complete, only in this way can carbon shell protect $\mathrm{CoS}_{2}$ particles effectively.

Fig. 4a exhibits the Raman spectroscopy of $\mathrm{CoS}_{2} / \mathrm{C}$. The peaks at $1590 \mathrm{~cm}^{-1}$ and $1358 \mathrm{~cm}^{-1}$ are commonly referred as G peak and D peak. ${ }^{29} \mathrm{G}$ peak is corresponding to a Raman active $\mathrm{E}_{2 \mathrm{~g}}$ mode of two-dimensional graphite layer, while D peak is attributed to a zone boundary phonon activated by disordered graphite or glass carbon..$^{30}$ The ratio of intensity between $\mathrm{D}$ peak and $\mathrm{G}$ peak $\left(I_{\mathrm{D}} / I_{\mathrm{G}}\right)$ is 0.65 . A general expression that gives the crystallite size (La) of graphite from the intensity ratio $I_{\mathrm{D}} / I_{\mathrm{G}}$ is given by
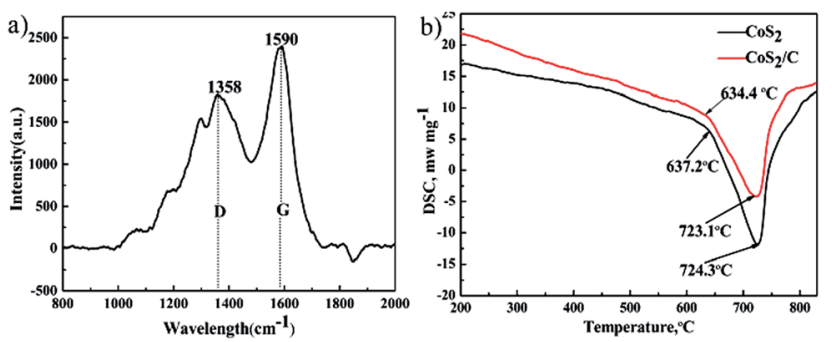

Fig. 4 Raman spectroscopy of $\operatorname{CoS}_{2} / \mathrm{C}$ (a). Differential scanning calorimeter of pristine $\mathrm{CoS}_{2}$ and $\mathrm{CoS}_{2} / \mathrm{C}(\mathrm{b})$. 


$$
\mathrm{La}(\mathrm{nm})=\frac{560}{E_{1}^{4}}\left(I_{\mathrm{D}} / I_{\mathrm{G}}\right)^{-1}
$$

where $E_{1}(2.41 \mathrm{eV})$ is the excitation laser energy used in the Raman experiment. ${ }^{31}$ The La of the carbon coating calculated by this formula is $25.5 \mathrm{~nm}$. It indicates that the carbon coating has considerable graphitic form and desirable electronic conductivity, which is necessary for the high power property at thermal batteries. In addition, no peak related to the $\mathrm{C}=\mathrm{C}$ fundamental stretching vibration of $\mathrm{S}_{2} \mathrm{C}=\mathrm{CS}_{2}$ configuration is observed at around $1445 \mathrm{~cm}^{-1}$. It reveals that no polymer is produced among interaction of $\mathrm{CoS}_{2}$ and sucrose.

Fig. $4 \mathrm{~b}$ gives results of differential scanning calorimeter of pristine $\mathrm{CoS}_{2}$ and $\mathrm{CoS}_{2} / \mathrm{C}$. Good thermal stability of cathode materials is a significant requirement at thermal batteries. Sulfide cathode materials with bad thermal stability may decompose and produce sulfur steam because the instantaneous high temperature at the beginning of activation, ${ }^{32}$ which leads fatal safe issues and loss of capacity. Only one endothermic peak related to decomposition of $\mathrm{CoS}_{2}$ is observed in both curves. The endothermic peak of pristine $\mathrm{CoS}_{2}$ is $724.3^{\circ} \mathrm{C}$, and that of $\mathrm{CoS}_{2} / \mathrm{C}$ is $723.1{ }^{\circ} \mathrm{C}$. In addition, approximate endothermic onset temperature that sample become decompose are pointed at two curves. DSC date can be inferred that the carbon coating has no apparent influence on the thermal stability of pristine $\mathrm{CoS}_{2}$.

According to the past studies, the discharge reactions of $\mathrm{CoS}_{2}$ included three steps which are expressed by following chemical reaction equations., ${ }^{1,33}$

$$
\begin{gathered}
(1-x) \operatorname{CoS}_{2}+(2-4 x) \mathrm{e}^{-} \rightarrow \operatorname{Co}_{(1-x)} \mathrm{S}+(1-2 x) \mathrm{S}^{-2} \\
\operatorname{Co}_{(1-x)} \mathrm{S}+\frac{2+16 x}{9} \mathrm{e}^{-} \rightarrow \frac{1-x}{9} \operatorname{Co}_{9} \mathrm{~S}_{8}+\frac{1+8 x}{9} \mathrm{~S}^{-2} \\
\mathrm{Co}_{9} \mathrm{~S}_{8}+16 \mathrm{e}^{-} \rightarrow 9 \mathrm{Co}^{0}+8 \mathrm{~S}^{-2}
\end{gathered}
$$

Correspondences of reaction equations are three plateau voltages. V. A. Bryukin inferred that $x$ was ranged from 0.110 to $0.124 .^{34}$ calculated by the theories of V. A. Bryukin, the specific capacity of first discharge plateau is $374-382 \mathrm{~mA} \mathrm{~h} \mathrm{~g}^{-1}$, that of second and third discharge plateau are $102-110 \mathrm{~mA} \mathrm{~h} \mathrm{~g}^{-1}$ and $348 \mathrm{~mA} \mathrm{~h} \mathrm{~g}^{-1}$ respectively.

Once a thermal battery is activated at the high temperature, self-discharge caused by dissolved lithium anode is remarkable. Thus, on the open circuit, the electromotive force (EMF) of the single cell will be decreased as time goes on due to active electrode materials are lost gradually by self-discharge reaction. Fig. 5a clarifies the relation between EMF and time of the battery cells fabricated with $\mathrm{CoS}_{2}$ and $\mathrm{CoS}_{2} / \mathrm{C}$ cathodes on the open circuit at $520{ }^{\circ} \mathrm{C}$ (single cells are designed with superfluous anode materials). EMF-time curves in the Fig. 5a reveal that active cathode materials are exhausted at last. There is no doubt that EMF of $\mathrm{CoS}_{2} / \mathrm{C}$ cell is decreased more slowly than that of pristine $\mathrm{CoS}_{2}$ cell. It can be concluded that $\mathrm{CoS}_{2} / \mathrm{C}$ cell has lower self-discharge rate than pristine $\mathrm{CoS}_{2}$ cell. Multiple EMF plateaus in the Fig. 5a represent phase transition of cathode materials. According to discharge process of $\mathrm{CoS}_{2}$, three open-circuit plateau voltages ordered from the most to the least are related to phases of $\mathrm{CoS}_{2}, \mathrm{Co}_{1-x} \mathrm{~S}, \mathrm{Co}_{9} \mathrm{~S}_{8}$ respectively. Fig. 5b shows differential capacity plots of cells. Three peaks located at $1.93 \mathrm{~V}$, $1.80 \mathrm{~V}, 1.57 \mathrm{~V}$ in differential capacity plots are also very consistent with open circuit voltage curves. The EMF of the reaction from $\mathrm{CoS}_{2}$ to $\mathrm{Co}_{1-x} \mathrm{~S}$ has been depressed by carbon coating.

In order to further validate above deductions, X-ray diffraction was applied for analyzing the composition of the cathode part which has experienced an open circuit losses. To prepare appropriate samples for XRD, $\mathrm{CoS}_{2} / \mathrm{C}$ cell and pristine $\mathrm{CoS}_{2}$ cell were laid on open circuit for $40 \mathrm{~min}$ at $520^{\circ} \mathrm{C}$ respectively. Then, cathode parts were rinsed with distilled water to remove electrolytes which will produce obvious interference signal. Fig. 6 displays XRD results of remainder active cathode materials which are obtained during open circuit. Diffraction spectrums show that the major phases of two samples are $\mathrm{CoS}_{2}$ and $\mathrm{Co}_{1-x} \mathrm{~S}$. Peaks located at $32.39^{\circ}$ (P1) and $35.18^{\circ}$ (P2) are contributed to $\mathrm{CoS}_{2}$ and $\mathrm{Co}_{1-x} \mathrm{~S}$ respectively. The mass ratio of $\mathrm{CoS}_{2}$ and $\mathrm{Co}_{1-x} \mathrm{~S}$ on the samples is directly proportional to intensity ratio of $\mathrm{P} 1$ and $\mathrm{P} 2(\mathrm{P} 1 / \mathrm{P} 2)$, and the $\mathrm{P} 1 / \mathrm{P} 2$ of $\mathrm{CoS}_{2} / \mathrm{C}$ cell is 0.83 , while for pristine $\mathrm{CoS}_{2}$ is 0.14 . Thus we can get the conclusion that there are less lost active materials on $\mathrm{CoS}_{2} / \mathrm{C}$ cell. Those results are consistent with the analysis of the EMF curve in Fig. 5a. It should be noted that obvious peaks related to $\mathrm{Co}_{9} \mathrm{~S}_{8}$ and $\mathrm{Co}_{3} \mathrm{~S}_{4}$ appear at two patterns. $\mathrm{Co}_{9} \mathrm{~S}_{8}$ phase may exist because of the non-uniform distribution of self-discharge reaction. A small amount of $\mathrm{Co}_{3} \mathrm{~S}_{4}$ can be related to thermal decomposition of $\mathrm{CoS}_{2} \cdot{ }^{35}$
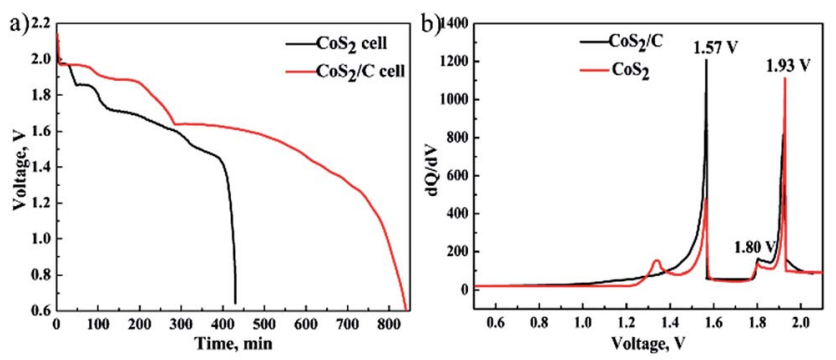

Fig. 5 The voltage of single cells as function of time on open circuit at $520{ }^{\circ} \mathrm{C}$ (a). Differential capacity plots of $\mathrm{CoS}_{2} / \mathrm{C}$ cell and pristine $\mathrm{CoS}_{2}$ (b).

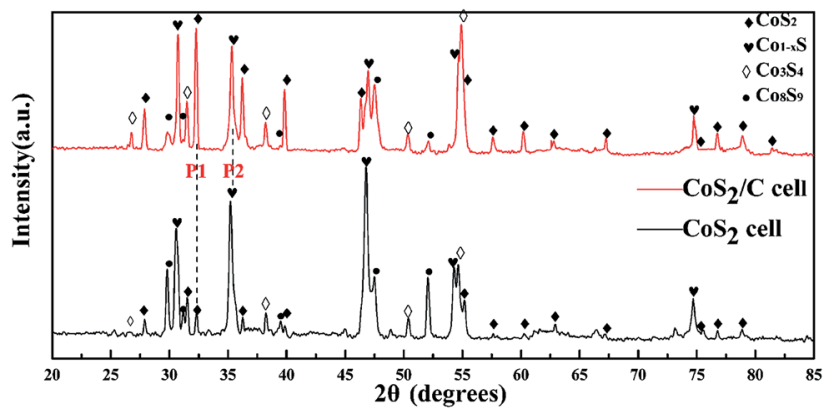

Fig. 6 XRD pattern of cathode electrode materials after 40 min on open circuit losses at $520^{\circ} \mathrm{C}$. 
Fig. 7 reports discharge curve of single cell that $\mathrm{Li}-\mathrm{B}$ alloy anode is superfluous at $100 \mathrm{~mA} \mathrm{~cm} \mathrm{~cm}^{-2}$ (a) and $500 \mathrm{~mA} \mathrm{~cm}^{-2}$ (b). It can be used to study electrochemical properties of cathode materials. Because only the capacity of first discharge plateau for $\mathrm{CoS}_{2}$ is utilized at practice application, specific capacity of first discharge plateau is regarded as standard to compare discharge capability of $\mathrm{CoS}_{2}$ cathode. Fig. 7a reveals that the specific capacity of first discharge plateau for $\operatorname{CoS}_{2} / \mathrm{C}$ is $243 \mathrm{~mA} \mathrm{~h} \mathrm{~g}^{-1}$, which is $50 \mathrm{~mA} \mathrm{~h} \mathrm{~g}^{-1}$ higher than of pristine $\mathrm{CoS}_{2}$, and accounts for $64.9 \%$ of the theoretical capacity of $\mathrm{CoS}_{2}$ $\left(374 \mathrm{~mA} \mathrm{~h} \mathrm{~g}^{-1}\right)$. In Fig. $7 \mathrm{~b}$, the specific capacity for first discharge plateau of $\mathrm{CoS}_{2} / \mathrm{C}$ and pristine $\mathrm{CoS}_{2}$ are $283 \mathrm{~mA} \mathrm{~h} \mathrm{~g}^{-1}$ and $258 \mathrm{~mA} \mathrm{~h} \mathrm{~g}^{-1}$, respectively. $\mathrm{CoS}_{2} / \mathrm{C}$ cells perform more flat and long first voltage plateau than pristine $\mathrm{CoS}_{2}$ cell. The carbon coating has a significant effect in increasing specific capacity whether at $500 \mathrm{~mA} \mathrm{~cm}{ }^{-2}$ or $100 \mathrm{~mA} \mathrm{~cm} \mathrm{~cm}^{-2}$. However, due to the loss of capacity caused by self-discharge will increase with discharge time, and completing discharge takes a longer time at $100 \mathrm{~mA} \mathrm{~cm}^{-2}$ than at $500 \mathrm{~mA} \mathrm{~cm}{ }^{-2}, \mathrm{CoS}_{2} / \mathrm{C}$ with lower self-discharge represents a more obvious advantage when single cells are discharged at the low current rate of $100 \mathrm{~mA} \mathrm{~cm}{ }^{-2}$.

Sustained self-discharge reactions will consume lithium from anode. Thus self-discharge rate at cathode has a great influence on the specific capacity of Li-B alloy anode. To compare the specific capacity of Li-B alloy anodes which are matched with different cathodes, single cells that cathode is

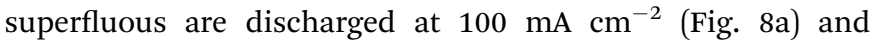
$500 \mathrm{~mA} \mathrm{~cm}^{-2}$ (Fig. 8b). In the Fig. 8a, as a result of using $\mathrm{CoS}_{2} / \mathrm{C}$ cathode, the specific capacity of $\mathrm{Li}-\mathrm{B}$ anode is increased from $805 \mathrm{~mA} \mathrm{~h} \mathrm{~g}^{-1}$ to $885 \mathrm{~mA} \mathrm{~h} \mathrm{~g}^{-1}$ at first plateau. In the Fig. $8 \mathrm{~b}$, an
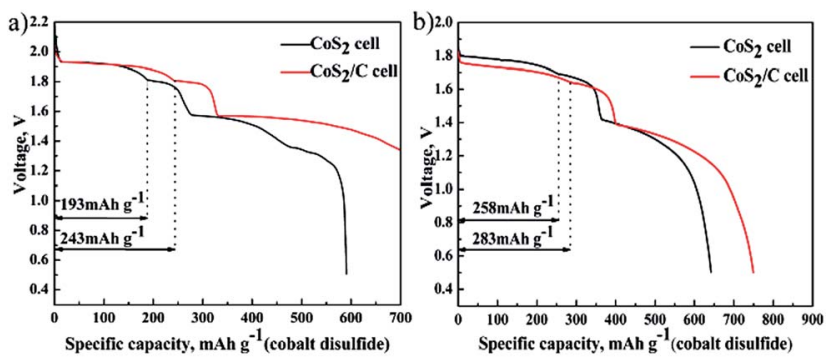

Fig. 7 Specific discharge capacity of cobalt disulfide cathode, data of pristine $\mathrm{CoS}_{2}$ cell or $\mathrm{CoS}_{2} / \mathrm{C}$ cell at $100 \mathrm{~mA} \mathrm{~cm}^{-2}$ (a) and $500 \mathrm{~mA} \mathrm{~cm}$ (b).
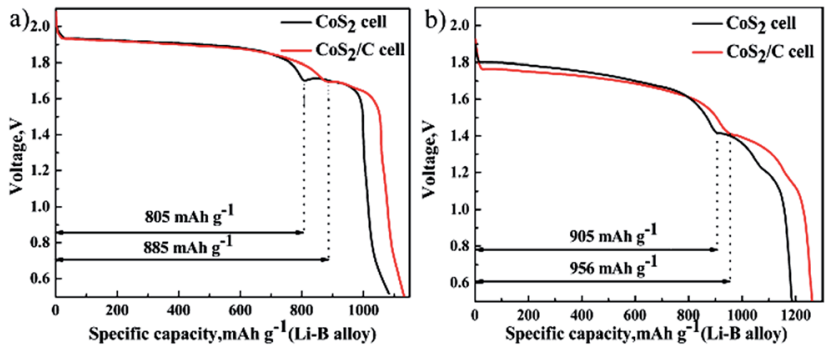

Fig. 8 Specific discharge capacity of $\mathrm{Li}-\mathrm{B}$ alloy anode, data of pristine $\mathrm{CoS}_{2}$ cell or $\mathrm{CoS}_{2} / \mathrm{C}$ cell at $100 \mathrm{~mA} \mathrm{~cm}^{-2}$ (a) and $500 \mathrm{~mA} \mathrm{~cm}^{-2}$ (b).
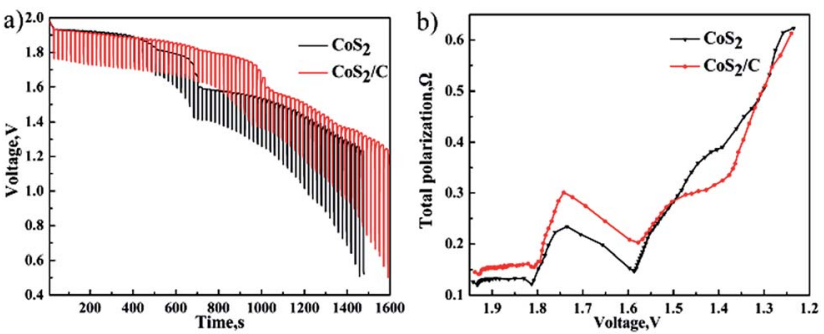

Fig. 9 Discharge performance at a background current of $100 \mathrm{~mA}$ $\mathrm{cm}^{-2}$ and pulse current of $600 \mathrm{~mA} \mathrm{~cm}{ }^{-2}$ for $2 \mathrm{~s}$ every $20 \mathrm{~s}($ a). Comparison of total polarization between $\mathrm{CoS}_{2}$ cell and $\mathrm{CoS}_{2} / \mathrm{C}$ cell (b).

increase of $51 \mathrm{~mA} \mathrm{~h} \mathrm{~g}^{-1}$ also appears on first discharge plateau of Li-B alloy anode. There is no doubt that $\mathrm{CoS}_{2} / \mathrm{C}$ cathode improves discharge efficient of Li-B alloy anode. The consequences of Fig. 8 provide further evidence that carbon coating on the $\mathrm{CoS}_{2}$ has evident effect in depressing self-discharge to the $\mathrm{Li}-\mathrm{B} / \mathrm{LiF}-\mathrm{LiCl}-\mathrm{LiBr} / \mathrm{CoS}_{2}$ cells. Li-B alloy is made up of lithium and LiB compound, which results in first and second discharge plateaus respectively. ${ }^{36}$ Besides, only lithium metal can dissolve into electrolytes and cause self-discharge. Therefore, $\mathrm{CoS}_{2} / \mathrm{C}$ cathode only has positive influence on the first discharge plateau of Li-B alloy anode.

In Fig. 7a and 8a, the first plateau voltage of $\mathrm{CoS}_{2} / \mathrm{C}$ cell is equal to pristine $\mathrm{CoS}_{2}$ cell at $100 \mathrm{~mA} \mathrm{~cm}{ }^{-2}$. In Fig. 7b and $8 \mathrm{~b}$, compared with pristine $\mathrm{CoS}_{2}$ cell, however, a decrease about $0.4 \mathrm{~V}$ to the plateau voltage appears at $\mathrm{CoS}_{2} / \mathrm{C}$ cell when the current density is increased to $500 \mathrm{~mA} \mathrm{~cm}{ }^{-2}$. Apparently, the carbon coating also has blocked diffusion of lithium ion, which produces additional concentration polarization for single cells at $500 \mathrm{~mA} \mathrm{~cm}{ }^{-2}$. The unique porous structure of amorphous carbon provide channels for the diffusion of lithium ion, which ensures enough lithium ion will diffuse to reaction interface in time at the low current density, but not at the high current density of $500 \mathrm{~mA} \mathrm{~cm} \mathrm{~cm}^{-2}$. To know the detail of polarization increased by the carbon coating and estimate properties of single cell at transitory high current, single cells were discharged at pulse loading mode. Fig. 9a depicts pulse discharge curve. The total polarization was calculated by previous formula. Fig. 9b compares the difference of total polarization between $\mathrm{CoS}_{2}$ cell and $\mathrm{CoS}_{2} / \mathrm{C}$ cell. The resistances of both cells are increased with discharge time. Though $\mathrm{CoS}_{2} / \mathrm{C}$ cell shows higher total polarization than $\operatorname{CoS}_{2}$ cell especially when the voltage is higher than $1.65 \mathrm{~V}$. $\mathrm{CoS}_{2} / \mathrm{C}$ cell also exhibits excellent performances at pulse current, which meets the requirement of delivering electricity with high power for thermal batteries.

\section{Conclusions}

In summary, to solve self-discharge problem at $\mathrm{Li}-\mathrm{B} / \mathrm{LiF}-\mathrm{LiCl}-$ $\mathrm{LiBr} / \mathrm{CoS}_{2}$ system, we have modified $\mathrm{CoS}_{2}$ with carbon coating by facile pyrolysis reaction of sucrose. Compare to the $\mathrm{CoS}_{2} / \mathrm{Li}-\mathrm{B}$ couple, thermal batteries fabricated with $\mathrm{CoS}_{2} / \mathrm{C}$ and Li-B alloy can deliver much higher specific capacity. The enhanced 
discharge efficiency can be explained by the mechanisms that the carbon coating can prevent $\mathrm{CoS}_{2}$ from directly exposing to the electrolytes and minimize the self-discharge reactions between the cathode and dissolved lithium. Besides, the carbonized process has no obvious influences on the thermal stability of pristine $\mathrm{CoS}_{2}$. It has been proved that $\mathrm{CoS}_{2} / \mathrm{C}$ was efficient and safe cathode materials. $\mathrm{CoS}_{2} / \mathrm{C}$ has great merits and value particularly at the long-life thermal batteries for the low self-discharge rate. The method of modifying cathode materials with carbon may be applied to other cathode materials such as $\mathrm{FeS}_{2}$ and $\mathrm{NiCl}$ for thermal batteries, all of those studies are underway.

\section{Conflicts of interest}

There are no conflicts of interest to declare.

\section{Acknowledgements}

This research work was financially supported by the National Natural Science Foundation of China (51771236), the Innovation-Driven Project of Central South University (No. 2017CX002).

\section{References}

1 R. A. Guidotti and P. Masset, J. Power Sources, 2006, 161, 1443-1449.

2 K. Nitta, S. Inazawa, S. Sakai, A. Fukunaga, E. Itani and K. Numata, SEI Tech. Rev., 2013, 76, 33-39.

3 P. Kulkarni, S. K. Nataraj, R. G. Balakrishna, D. H. Nagarajua and M. V. Reddy, J. Mater. Chem. A, 2017, 5, 22040-22094.

4 M. Chen, X. Yin, M. V. Reddy and S. Adams, J. Mater. Chem. A, 2015, 3, 10698-10702.

5 S. Fujiwara, M. Inaba and A. Tasaka, J. Power Sources, 2010, 195, 7691-7700.

6 R. A. Guidotti and P. Masset, J. Power Sources, 2008, 183, 388398.

7 A. J. Burak and M. F. Simpson, JOM, 2016, 68, 1-7.

$8 \mathrm{~N}$. Watanabe, K. Nakanishi and A. Komura, Journal of the Society of Chemical Industry Japan, 1968, 71, 1599-1602.

$9 \mathrm{~J}$. X. Gao, Microcosmic characteristics and discharge properties of cobalt sulfide as cathode in thermal batteries, Central South University, 2014.

10 P. Zeng, Dissolution characteristics and discharge properties of LiB alloys as anode in thermal batteries, Central South University, 2016.

11 F. Wu, Q. Xue, L. Li, X. Zhang, Y. Huang and E. Fan, RSC Adv., 2017, 7, 1191-1199.

12 P. R. Kumar, V. Madhusudhanrao and B. Nageswararao, J. Solid State Electrochem., 2016, 20, 1855-1863.
13 M. V. Reddy, G. V. Subba Rao and B. V. Chowdari, Chem. Rev., 2013, 113, 5364-5457.

14 S. Amaresh, K. Karthikeyan and K. J. Kim, $R S C$ Adv., 2014, 4, 23107-23115.

15 M. Seungtaek, I. Kentarou and K. Shinichi, J. Mater. Chem., 2005, 17, 3695-3704.

16 M. Yoshio, H. Wang and K. Fukuda, J. Electrochem. Soc., 2000, 147, 1245-1250.

17 S. Petnikota, S. K. Marka, A. Banerjee, M. V. Reddy, V. V. S. S. Srikanth and B. V. R. Chowdari, J. Power Sources, 2015, 293, 253-263.

18 S. Petnikota, V. V. S. S. Srikanth, P. Nithyadharseni, M. V. Reddy, S. Adams and B. V. R. Chowdari, ACS Sustainable Chem. Eng., 2015, 3, 3205-3213.

19 S. Petnikota, S. K. Marka, V. V. S. S. Srikanth, M. V. Reddy and B. V. R. Chowdari, Electrochim. Acta, 2015, 178, 699-708.

20 L. Wang, Z. Liu, Q. Guo, X. Guo and J. Gu, RSC Adv., 2017, 7, 36735-36743.

21 S. Petnikota, N. K. Rotte, V. V. S. S. Srikanth, B. S. R. Kota, M. V. Reddy and K. P. Loh, J. Solid State Electrochem., 2014, 18, 941-949.

22 S. Xie, Y. Deng and J. Mei, Electrochim. Acta, 2017, 231, 287293.

23 S. Amaresh, K. Karthikeyan and I. C. Jang, J. Mater. Chem. A, 2014, 2, 11099-11106.

24 J. Dong, D. Li and Z. Peng, J. Solid State Electrochem., 2008, 12, 171-174.

25 J. Wang and X. Sun, Energy Environ. Sci., 2012, 5, 5163-5185.

26 Z. J. Liu, Z. Y. Li, W. Duan, X. H. Qu, B. Y. Huang and S. Q. Zhang, J. Mater. Sci. Technol., 2000, 16, 581-584.

27 S. Xie, Y. Deng, J. Mei, Z. Yang, W. M. Lau and H. Liu, Composites, Part B, 2016, 93, 203-209.

28 M. Hurtta, I. Pitkänen and J. Knuutinen, Carbohydr. Res., 2004, 339, 2267-2273.

29 J. Schwan, S. Ulrich and V. Batori, J. Appl. Phys., 1996, 80, 440-447.

30 A. C. Ferrari and J. Robertson, Phys. Rev. B: Condens. Matter Mater. Phys., 2008, 61, 14095-14107.

31 L. G. Cancado, K. Takai and T. Enoki, Appl. Phys. Lett., 2006, 88, 163106.

32 S. Serge, J. Power Sources, 2005, 142, 361-369.

33 Y. Wang, J. Wu, Y. Tang, X. Lu, C. Yang and M. Qin, ACS Appl. Mater. Interfaces, 2012, 4, 4246-4250.

34 V. A. Bryukvin and L. I. Blokhina, Nickel-Cobalt International 97 Symposium, Canada, August 1997.

35 M. A. Rodriguez, E. N. Coker, J. J. M. Griego, C. D. Mowry, A. S. Pimentel and T. M. Anderson, Powder Diffr., 2016, 31, 90-96.

36 P. Sanchez, C. Belin, G. Crepy and A. D. Guibert, J. Mater. Sci., 1992, 27, 240-246. 